Л. Карамушка, Т. Сорочан; за ред.В. Олійника, Н. Протасової. - Луганськ : СПД Рєзніков В. С., 2011. - 308 с. 8. Сергеєва Л. М. Управління розвитком професійнотехнічного навчального закладу: теорія і методика :[монографія] / Л. М. Сергеєва; за наук. ред.В. В. Олійника. - К.; Херсон : Айлант, 2013. - 452 с. 9. Сущенко Т. І. Провідні фактори концептуального впливу на управління освітніми процесами/ T. I. Сущенко // Педагогіка формування творчої особистості у вищій i загальноосвітній школах : зб. наук. пр. - Запоріжжя, 2009. - Вип. 56. - С. 373-379. 10. Теоретичні і методичні засади моделювання фахової компетентності керівників закладів освіти: [монографія] / Г. В. Сльникова, О. І. Зайченко, В. І. Маслов та ін.; за ред. Г. В. Сльникової. - К.; Чернівці : Книги - XXI, 2010. - 460 с. 11. Федоров Г. В. Системний підхід до управлінської діяльності керівника навчальних закладів у ринкових умовах : [монографія] / Г. В. Федоров. - К. : ДорадоДрук, 2012. - 240 с.

Аліна Дуднік

\title{
ПЕДАГОГІЧНІ УМОВИ ПІДГОТОВКИ МАЙБУТНІХ УЧИТЕЛІВ ПОЧАТКОВОЇ ШКОЛИ ДО ОРГАНІЗАЦЇ̈ ГРУПОВИХ ФОРМ ПІЗНАВАЛЬНОЇ ДІЯЛЬНОСТІ
}

Дуднік А. О. Педагогічні умови підготовки майбутніх учителів початкової школи до організації групових форм пізнавальної діяльності.

У статті обгрунтовано необхідність дотримання педагогічних умов підготовки майбутніх учителів початкової школи до організації групових форм пізнавальної діяльності. Розглянуто пріоритетні напрями і форми діяльності педагога, що забезпечують формування професійної компетентності майбутніх фахівців.

Ключові слова: професійно-педагогічна діяльність, професійна компетентність, педагогічні умови, групові форми, пізнавальна діяльність.

Дудник А. А. Педагогические условия подготовки будущих учителей начальной школы к организации групповых форм познавательной деятельности.

В статье обоснована необходимость придерживаться педагогических условий подготовки будущих учителей начальной школы к организации групповых форм познавательной деятельности. Рассмотренны приоритетные направления и формы деятельности педагога, которые обеспечивают формирование профессиональной компетентности будущих специалистов.

Ключевые слова: профессионально-педагогическая деятельность, профессиональная компетентность, педагогические условия, групповые формы, познавательная деятельность.

Dudnik A. A. Pedagogical Conditions for Preparing Would-be Primary School Teachers for the Organization of the Group Forms of Learning.

The article proves the necessity to implement the pedagogical conditions for preparing would-be primary school teachers for the organization of the group forms of learning. The article examines the main forms of the pedagogical activity of a teacher, who can provide the formation of the professional competence of would-be teachers.

Key words: professional pedagogical activity, professional competence, pedagogical conditions, group forms, learning. 
Інноваційні процеси, притаманні сучасній системі вітчизняної вищої освіти, віддзеркалюючи досягнення в усіх галузях природничих і гуманітарних наук, мають на меті підвищити іiі ефективність. Один зі шляхів розв'язання цього завдання вбачається у впровадженні у зміст діяльності вищої школи педагогічних технологій, спрямованих на його вдосконалення, розвиток мотивації студентів до навчання, підвищення пізнавальної активності й самостійності, розвиток якостей, які сприяли б активному залученню особистості до творчої перетворювальної діяльності як передумови оптимізації професійно-педагогічної підготовки.

Лише в цьому випадку можна сподіватися на підготовку майбутнього вчителя, насамперед початкової школи, здатного до впровадження інноваційних технологій у традиційну класно-урочну систему, а також у форми та методи організації навчання поза її межами.

Змістові аспекти проблеми оновлення національної освіти в цьому аспекті відображено у працях В. Бондаря, В. Гузєєва, М. Євтуха, І. Зязюна, Ю. Краснова, В. Кременя, В. Лутковського, Н. Ничкало, Н. Побірченко, О. Пометун, С. Сисоєвої, М. Сметанського та ін. [2, с. 35].

Як засвідчують дослідження, конкурентоспроможні в освітньому просторі випускники педагогічних напрямів підготовки загалом складають незначну кількість (10-15\%). Підвищити рівень кваліфікації майбутнього вчителя та якість його підготовки, забезпечити готовність випускника ВНЗ до результативної професійнопедагогічної діяльності можливо за умов гнучкого поєднання особистісного та фахового складників у системі навчання. Це передбачає перехід від традиційнопредметного навчання й оцінювання до адаптовано-індивідуального опанування професії вчителя 3 перших кроків становлення за програмною цілеспрямованою педагогічною взаємодією і співпрацею студента та викладача, який добре володіє педагогічними прийомами, враховує навчально-пізнавальні можливості і здатності кожної особистості [1, с. 36].

Одним зі стратегічних завдань реформування освітньої галузі, визначених Національною доктриною розвитку освіти України, $\epsilon$ впровадження мобільної системи підвищення професіоналізму педагогів, спрямованої на розвиток інтелектуального потенціалу, психологічної компетентності, здатності до ефективної педагогічної діяльності [4, с. 52].

Сучасному вчителеві недостатньо володіти лише своїм предметом, необхідно знати особливості його засвоєння учнями, формувати в них потребу в оволодінні метазнаннями (знаннями про знання) тощо. Отже, зміст професійної компетентності вчителя охоплює сформованість як предметних, так і методичних знань, а також професійних (знання про основні напрями й зміст праці вчителя, сутність та особливості професійно-педагогічної діяльності, розвиток педагогічної i психологічної наук, професійну підготовку тощо).

Останніми роками в України запроваджується новий Державний стандарт початкової загальної освіти. Зважаючи на це, вчителю потрібно пам'ятати, що у вихованні все повинно грунтуватися на особі педагога, тому що виховна сила витікає тільки 3 живого джерела людської особистості. Ніякі статути і програми, ніякий штучний організм закладу, хоч би як грунтовно він був продуманий, не може замінити особистості у справі виховання. Особливо це стосується вчителя початкової школи, адже він створює розвивально-освітнє середовище, організовує поведінку й діяльність дітей та є для них безумовним авторитетом і прикладом для наслідування. 
Очевидно, що саме від якості вищої педагогічної освіти, рівня сформованості професійної компетентності й особистісного розвитку студентів - майбутніх учителів - значною мірою залежатиме якість початкової освіти. Тому необхідно шукати нові шляхи (засоби і методи) професійної підготовки студентів педагогічних спеціальностей [9, с. 47].

Серед форм і методів, зорієнтованих на оптимізацію вищої освіти, помітне місце посідає впровадження в навчально-виховний процес групових форм пізнавальної діяльності. I хоча ці форми не нові для педагогічної теорії та практики, інтерес до них не слабшає і нині. Передумовою цього є два основні мотиви. Перший - це пошук методів, які давали б змогу представити освітній процес як організацію переважно самостійної роботи студентів. Другий - прагнення розглядати освіту ширше, ніж просто передачу певного обсягу знань. Не можна нехтувати й тим, що групові форми пізнавальної діяльності висуваються на перший план як методи сучасної освіти [2, с. 36].

Отже, проблема підготовки майбутнього вчителя початкової школи до організації групових форм пізнавальної діяльності $\epsilon$ надзвичайно актуальною і соціально значущою, однак недостатньо теоретично розробленою та практично реалізованою. У змісті аудиторної діяльності сучасного педагогічного інституту визначено пріоритетні напрями і форми діяльності, реалізація яких має забезпечити формування професійної компетентності майбутніх фахівців. Наше дослідження не претендує на остаточне розв'язання означеної проблеми, детального вивчення потребують окремі нові форми, які в поєднанні 3 наявним досвідом і традиціями допоможуть підготувати компетентного вчителя початкової школи.

Mema cmammi: схарактеризувати педагогічні умови підготовки майбутніх учителів початкової школи до організації групових форм пізнавальної діяльності.

На думку Ч. Мейєрса та Т. Джонса, навчання студентів стає активним, коли викладачі поступаються місцем у центрі освітнього процесу студентам і допомагають їм брати на себе більше відповідальності за навчання. Вагому роль у цьому дослідники відводять груповій формі пізнавальної діяльності. 3 погляду результатів навчання, метод групової форми пізнавальної діяльності має багато спільного 3 методом роботи у неформальних малих групах, де студенти мають змогу:

- удосконалювати мислення в спілкуванні та письмі, а також навички групового спілкування;

- порівнювати власні думки з думками інших;

- давати оцінку новим підходам;

- аргументувати власну позицію.

Проте групові форми пізнавальної діяльності потребують від студентів уміння практично застосовувати позитивну взаємодію і нести індивідуальну відповідальність, здійснювати складнішу групову активність. Крім того, групи виконують спільну роботу протягом тривалішого часу, вони можуть разом працювати над такими проектами, за які студенти отримують загальну оцінку або завдяки яким забезпечується зворотний зв'язок, що акцентує на індивідуальних проектах студентів [2, с. 37].

Важливим показником професійно-педагогічної діяльності є компетентність, що потребує від учителя вміння синтезувати матеріал для успішного розв'язання педагогічних завдань, аналіз ситуацій, що зумовлюють необхідність осмислення психологічної сутності явищ, вибору засобів взаємодії. На основі професійних завдань формується педагогічна свідомість - принципи і правила, які є засадничими щодо дій і вчинків учителя. Ці принципи та правила педагог виробляє на основі власного досвіду, але осмислити, усвідомити їх можна лише за допомогою наукових 
знань, що потребують систематичного поповнення. Варто зауважити, що складність навчання педагога, набуття професійної компетентності полягає i в тому, що професійне знання має формуватися одночасно на всіх рівнях - методологічному, теоретичному, методичному, технологічному. Це потребує розвиненого професійного мислення, здатності добирати, аналізувати й синтезувати набуті знання в досягненні педагогічної мети, уявляти технологію їх застосування [5, с. 59].

Державним стандартом початкової загальної освіти поставлені досить високі вимоги до рівня загальноосвітньої підготовки сучасного учня. Аналіз документів дає підстави зробити висновки, що нині вже неможливо навчати традиційно: у центрі навчально-виховного процесу має бути учень. Від його творчої активності на уроці, вміння доказово міркувати, обгрунтувати свої думки, спілкуватися з учителем, учнями класу залежить успіх у свідомому опануванні шкільної програми. Досягненню такої мети сприяє підготовка майбутніх учителів початкової школи до організації групових форм пізнавальної діяльності.

Досвід роботи засвідчує, що використання групових форм пізнавальної діяльності в умовах вищої школи підвищує інтерес майбутніх педагогів до навчання. Саме тому в дослідженні намагаємося здійснити комплексний аналіз педагогічних умов підготовки майбутніх учителів початкової школи до організації групових форм пізнавальної діяльності, спрямованої на розроблення й обгрунтування її ефективної організації на основі визнання абсолютної специфічності порівняно 3 традиційним навчальним процесом, який здійснюється у вищій педагогічний школі.

Нині до цієї проблеми спостерігається особливий інтерес, пов'язаний, передусім, 3 новими підходами щодо організації навчання у вищій школі в контексті Болонського процесу (А. Алексюк, Б. Бокуть, Я. Болюбаш, І. Зязюн, В. Кремень, Н. Кузьміна, 3. Курлянд, О. Молібог, Н. Ничкало та ін.), а також із новими стратегічними завданнями вітчизняної освіти, визначеними в стрижневих нормативних документах Законах України «Про освіту», «Про вищу освіту», Державній програмі «Учитель», Державному стандарті вищої освіти, Національній доктрині розвитку освіти України в XXI столітті.

У зв'язку з цим, вищі педагогічні навчальні заклади спрямовують свої зусилля, 3 одного боку, на підвищення якості навчання студентів і набуття ними необхідних знань в умовах становлення української державності, надання сталої вагомості українській ментальності, а 3 іншого, - на формування особистості майбутнього вчителя, здатного до самостійного навчання, який би у своїй подальшій роботі з учнями активно впроваджував у практику викладання групові форми пізнавальної діяльності [6, с. 5].

Найсуттєвішими рисами, які характеризують кооперативні студентські проекти, Ч. Мейєрс та Т. Джонс уважають:

- залежність учасників від групи як цілого сприяє успішному завершенню завдання;

- ураховуючи індивідуальність навичок, перед учасниками можна ставити різні завдання, щоб забезпечити їхній внесок у груповий проект;

- зміст навчального завдання може виявитися більш складним, i тоді групи працюють у позааудиторний час, а не лише за розкладом;

- важливі соціальні навички значно ширші, ніж просто слухання i запам'ятовування (тут є місце для створення і отримання позитивного зворотного зв'язку, а також для формування навичок критики групового процесу як цілого);

- викладачі постають співучнями або майстер-учнями, допомагаючи групам утримувати напрям і надаючи ресурси для виконання групових завдань. 
Перспективним уважаємо вивчення взаємозв'язку між уміннями майбутніх учителів долучатися до виконання навчальних проектів i працювати на засадах кооперації та їхньою здатністю використовувати відповідні методи у своїй професійно-педагогічної діяльності [2, с. 37].

Зазначене вище свідчить, що організація групових форм пізнавальної діяльності майбутніх учителів початкової школи стане можливою за умови забезпечення комплексного підходу до організації навчального процесу у ВНЗ і реалізації таких дидактичних умов:

- інтенсифікація навчання завдяки залученню студентів до системи «студент метод пізнання - методи й засоби пізнання»;

- тісний взаємозв'язок навчально-дослідної та навчально-пізнавальної діяльності;

- активізація пізнавальної діяльності засобом виконання групових форм роботи;

- формування в майбутніх учителів початкової школи навичок організації групових форм пізнавальної діяльності;

- створення ситуації успіху для кожного учасника пізнавальної діяльності групових форм роботи;

- створення сприятливих умов для підготовки майбутніх учителів початкової школи до організації групових форм пізнавальної діяльності.

Отже, основний зміст технології групових форм навчання має становити методика застосування проблемних ситуацій на різних етапах заняття в пізнавальній діяльності студентів.

Професійні педагогічні знання майбутнього вчителя початкової школи відіграють важливу роль у пошуках шляхів безперервного, послідовного підведення учнів початкової ланки освіти до сприйняття і самостійного розв'язання завдань, які постійно ускладнюються. Тому однією 3 основних проблем, що стоять перед педагогом, є пошук і розв'язання системи завдань протягом усього навчання.

Одним із найважливіших результатів процесу навчання студентів $є$ бажаний рівень формування в них пізнавальної діяльності. Ефективним методом стимулювання пізнавального інтересу є організація групових форм пізнавальної діяльності.Ситуативні, рольові й особливо ділові ігри яскраво демонструють практичну необхідність знань студентів. Використання групових форм у процесі вивчення навчального матеріалу стимулює пізнавальну діяльність майбутніх учителів початкової школи.

За даними нашого дослідження, групові форми роботи в практиці вищої школи $є$ ефективним методом підготовки майбутніх учителів початкових класів, вони стимулюють пізнавальний інтерес студентів за допомогою організації та характеру пізнавальної діяльності. Групові форми роботи у вищій школі створюють емоційний тонус діяльності, формують правильні стосунки змагання та взаємної підтримки під час навчання і позитивно впливають на взаємини у групі.

Отже, основна мета організації групових форм пізнавальної діяльності в підготовці майбутніх учителів початкової школи - це відпрацювання навичок колективної діяльності під час ефективного розв’язання професійних завдань.

\section{Література}

1. Бондар В. Адаптоване навчання студентів як передумова реалізації компетентнісного підходу до професійної підготовки вчителя / Володимир Бондар, Ірина Шапошнікова // Рідна школа. - 2013. - № 11. - С. 36-39. 2. Ващенко О. Метод проектів і кооперативне навчання як засіб оптимізації вищої освіти / Олена Ващенко, Тамара Кравченко // Початкова школа. - 2013. - № 1. - С. 35-37. 3. Заворотнюк О. Формування професійної компетентності майбутніх психологів у позааудиторній діяльності / Оксана Заворотнюк// Рідна школа. - 2013. - № 11. - С. 65-68. 
4. Кочерга О. Розвиток психологічної компетентності вчителя початкової школи / Олександр Кочерга // Рідна школа. - 2013. - № 11. - С. 52-53. 5. Макаренко А. С.Собрание соченений: В 7-ми томах / А. С. Макаренко. - М.: Изд-во АПН РФСР, 1957.- Т. 4. Лекции о воспитании детей. - С. 59. 6. Малихін О. В. Організація самостійної навчальної діяльності студентів вищих педагогічних навчальних закладів: теоретико-методологічний аспект: [монографія] / Олександр Володимирович Малихін. - Кривий Ріг : Видавничий дім, 2009. - 307 с. 7. Мейерс Ч. Кооперативные студенческие проекты / Ч. Мейерс, Т. Джонс// Метод проектов в университетском образовании; под общ. ред. М. А. Гусаковского. - Минск: БГУ, 2008. C. 80-96. 8. Національна доктрина розвитку освіти України. - Інфордиск «Законодавство України». - 2007. - № 2. 9. Пошкуратова Т. Практична підготовка студентів - одне 3 найголовніших завдань педагогічної освіти / Тамара Пошкуратова // Початкова школа. - 2013. - № 10. - С. 47-50. 10. Пускаева Т. Д. Современные модели кооперированного обучения: методики США / Т. Д. Пускаева// Химия в школе.1993. - № 3. - C. 43-45.

\section{ДО ПИТАННЯ ПРО ВПЛИВ ПРОФЕСІЙНОЇ САМООРГАНІЗАЦЇ̈ НА ФОРМУВАННЯ ПЕДАГОГІЧНОГО ПРОФЕСІОНАЛІЗМУ МАЙБУТНІХ УЧИТЕЛІВ}

Дуднік Н. Ю. До питання про вплив професійної самоорганізації на формування педагогічного професіоналізму майбутніх учителів.

У статті розглянуто деякі теоретичні підходи щодо визначення поняття «педагогічний професіоналізм». Проаналізовано вплив професійної самоорганізації на розвиток професіоналізму майбутніх учителів. Порівняно зміст понять «професійна самоорганізація» та «самоорганізація професійної діяльності».

Ключові слова: педагогічний професіоналізм, професійна самоорганізація, самоорганізація професійної діяльності, майбутні вчителі.

Дудник Н. Ю. К вопросу о влиянии профессиональной самоорганизации на формирование педагогического профессионализма будущих учителей.

В статье рассматриваются некоторые теоретические подходы к определению понятия «педагогический профессионализм». Проанализировано влияние профессиональной самоорганизации на развитие профессионализма будущих учителей. Проведено сравнение содержания понятий «профессиональная самоорганизация» и «самоорганизация профессиональной деятельности».

Ключевые слова:педагогический профессионализм, профессиональная самоорганизация, самоорганизация профессиональной деятельности, будущие учителя.

Dudnik N. Yu. The effect of the professional self-organization on the formation of professional pedagogical professionalism of future teachers.

The article considers some theoretical approaches to defining the notion of «pedagogical professionalism». It also provides the influence of professional selforganization on the development of future teachers' professionalism. The comparison of content of such concepts as «professional self-organization» and «self-organization of professional activity» is given.

Key words:pedagogical professionalism, professional self-organization, self- 